\title{
LITIGÂNCIA CLIMÁTICA COMO INSTRUMENTO INDUTOR DA DESCARBONIZAÇÃO DA MATRIZ ENERGÉTICA BRASILEIRA
}

\section{CLIMATE LITIGATION AS AN INDUCTIVE INSTRUMENT FOR THE DECARBONIZATION OF THE BRAZILIAN ENERGY MATRIX}

\author{
Letícia Albuquerque ${ }^{1}$ \\ Gabrielle Tabares Fagundez ${ }^{2}$ \\ Marcelo Pretto Mosmann ${ }^{3}$
}

\begin{abstract}
RESUMO: O objetivo deste artigo é analisar a transiçăo energética com foco nas fontes renováveis e no abandono dos combustíveis fósseis, no contexto da crise multidimensional que a humanidade atravessa, de caráter econômico, social e ecológico. O trabalho é desenvolvido pelo método dedutivo, a partir da análise documental e bibliográfica acerca dos temas associados à matriz energética, levando em conta a crise multidimensional e a ascensăo de movimentos de justiça climática e casos de litigância climática. A hipótese aventada é a de que a transiçấo da matriz energética brasileira tem no uso de energias renováveis vantagens comparativas com relaçăo aos demais países, com benefícios do ponto de vista dos reduzidos impactos ao meio ambiente, ao clima e às populaçôes humanas se comparadas às fontes provenientes de combustíveis fósseis. Os resultados indicam que o foco nas energias renováveis é o modelo mais adequado à transiçăo da matriz energética brasileira, evitando o incremento das injustiças climáticas e dos casos de litigância climática associados aos efeitos traumáticos da extraçâo e queima de carvâo mineral para as populaçóes
\end{abstract}

\footnotetext{
1 Professora dos cursos de Graduaçáo e Pós-graduaçấo em Direito da Universidade Federal de Santa Catarina (UFSC), onde co-dirige o Observatório de Justiça Ecológica - Grupo de Pesquisa cadastrado no CNPq. Graduada em Ciências Jurídicas e Sociais pela Pontifícia Universidade Católica do Rio Grande do Sul (1997), especializaçăo em Integraçáo e Mercosul pela Universidade Federal do Rio Grande do Sul (1998) e mestrado em Direito pela Universidade Federal de Santa Catarina (2002), com ênfase em Relaçôes Internacionais e Meio Ambiente. Doutora em Direito pela Universidade Federal de Santa Catarina (2004-2009) com estágio de doutoramento realizado na Faculdade de Direito de Coimbra, Portugal (2006), com bolsa de estudos da CAPES. Tem experiência na área de Direito Público, com ênfase em Direito Internacional, Direito Ambiental e Direitos Humanos, atuando principalmente nos seguintes temas: justiça ambiental e direitos humanos; proteçăo internacional do meio ambiente .Membro do Conselho Nacional do Meio Ambiente-CONAMA (2015-2017). Pesquisadora do Laboratório SAGE (Sociétés, Acteurs, Gouvernement en Europe), Université de Strasbourg (França), onde realizou estágio de pós-doutorado com bolsa de estudos da CAPES (09/2017-08/2018). Bolsista de Produtividade em Pesquisa do CNPq. laettitia.ufsc@gmail.com

2 Doutoranda no Programa de Pós-Graduaçáo em Direito da Universidade Federal de Santa Catarina - PPGD/ UFSC. Mestre em Direito pelo PPGD/UFSC. Pesquisadora do Observatório de Justiça Ecológica - grupo de pesquisa cadastrado no CNPq. Desenvolve pesquisa nas áreas de Direito Ambiental, Direitos Humanos e Direito Animal. fagundez.gabrielle@gmail.com

3 Mestrando pelo Programa de Pós-Graduaçăo em Direito da Universidade Federal de Santa Catarina - PPGD/ UFSC. Pesquisador do Observatório de Justiça Ecológica - grupo de pesquisa cadastrado no CNPq. Especialista em Direito Processual Civil pela Universidade Federal do Rio Grande do Sul(2008), graduado em Ciências Jurídicas e Sociais - Direito pela Universidade Federal do Rio Grande do Sul(2007).mosmann@hotmail.com
} 
humanas e para meio ambiente em nível local e global.

Palavras-chave: Energias Renováveis. Emissōes de Carbono. Crise Ecológica. Justiça Climática. Litigância Climática.

ABSTRACT: The purpose of this paper is to analyze the energy transition with focus on renewable sources and the abandonment of fossil fuels, in the context of the multifaceted crisis crossed by humanity, of economic, social and ecological character. The work is developed by the deductive method, from the documentary and bibliographical analysis on the themes associated with the energy matrix, taking into account the multidimensional crisis and the rise of climate justice movements and cases of climate litigation. The hypothesis is that the transition of the Brazilian energy matrix has comparative advantages in the use renewable sources in relation to other countries, with benefits from the point of view of the reduced impacts to the environment, climate and human populations when compared to the sources from fossil fuels. The results indicate that the focus on renewable sources is the most appropriate model for the transition of the Brazilian energy matrix, avoiding the increase of climate injustices and cases of climate litigation associated with the traumatic effects of coal extraction and burning for human populations and the environment at local and global level.

Keywords: Renewable Energies. Carbon Emissions. Ecological Crisis. Climate Justice. Climate Litigation.

\section{INTRODUÇÃO}

A humanidade do século XXI enfrenta problemas cujas soluçōes desafiam o ser humano a romper com modelos tradicionais de exploraçấo dos recursos naturais. A emergência do aumento da concentraçăo de gases de efeito estufa na atmosfera e as alteraçôes climáticas a ele associadas já demandaram a adoçâo de diversos protocolos internacionais, sendo o mais conhecido o já ultrapassado Protocolo de Kyoto, firmado em 1998, e o mais recente o Acordo de Paris, fundado na lógica do respeito à soberania dos estados nacionais.

Tais esforços justificam-se pelas previsóes do Painel Intergovernamental de Mudança Climática (IPCC, na sigla em inglês) que estabelece cenários e previsōes para os possíveis efeitos das mudanças climáticas, com a elevaçăo dos níveis dos oceanos, a ocorrência de eventos extremos em maior intensidade, e o aumento da temperatura em determinadas regiōes do planeta. $O$ fato desses efeitos apresentarem-se de maneira heterogênea e nâo uniforme justifica as preocupaçôes com a adaptabilidade das populaçóes humanas mais vulneráveis a estes efeitos, questăo que vem sendo levada em conta com seriedade em diversos países no âmbito da litigância climática.

Nesse contexto global, o Brasil é uma naçăo que se apresenta com grande vantagem com relaçấo a maioria dos demais países, seja pela matriz energética baseada em grande parte na energia hidrelétrica - que embora tenha suas desvantagens, é uma matriz renovável - seja pela vasta extensāo territorial e condiçôes ambientais favoráveis à produçăo de biomassa, que permite a mitigaçăo da emissăo de gases de efeito 
estufa no processo de produçăo de energia. Ainda assim, na contramăo da tendência global de transiçáo para fontes renováveis, um projeto da década de 1970 relacionado à extraçăo e queima de carvấo mineral foi reativado no Estado do Rio Grande do Sul, com a proposta de instalaçăo da maior mina de carvăo a céu aberto do Brasil.

Assim, é objetivo deste artigo analisar a transiçáo energética com foco nas fontes renováveis e no abandono dos combustíveis fósseis, no contexto da crise multidimensional que a humanidade atravessa, a qual apresenta um caráter econômico, social e ecológico. O trabalho é desenvolvido pelo método dedutivo, a partir da análise documental e bibliográfica acerca dos temas associados à matriz energética, levando em conta os marcos teóricos da crise multidimensional e a ascensăo de movimentos de justiça climática e de casos de litigância climática.

Com isso, busca-se verificar a hipótese de que a transiçăo da matriz energética brasileira encontra na alternativa da biomassa vantagens comparativas com relaçáo aos demais países, com benefícios do ponto de vista dos reduzidos impactos ao meio ambiente, ao clima e às populaçōes humanas se comparada às fontes provenientes de combustíveis fósseis.

Para tanto, no primeiro desenvolvimento é analisada a situaçăo geral da matriz energética brasileira e as possibilidades de transiçâo rumo ao incremento das energias renováveis, bem como a utilizaçăo do carvăo mineral no contexto da crise de caráter multidimensional. No segundo desenvolvimento, este contexto é examinado com foco nas questōes associadas à justiça ambiental e à emergência de casos de litigância climática, voltados à mitigaçấo, adaptaçăo, reparaçăo e gestăo de riscos.

A partir da análise proposta, sâo retiradas as conclusōes aplicáveis ao contexto brasileiro com destaque nas possibilidades do uso da biomassa como modelo de transiçấo da matriz energética, como alternativa aos efeitos traumáticos da extraçăo e queima de carvăo mineral para as populaçôes humanas e para o meio ambiente em nível local e global.

\section{A CRISE MULTIDIMENSIONAL E O PAPEL DAS ENERGIAS RENOVÁVEIS COMO ALTERNATIVA AO CARVÃO MINERAL NA TRANSIÇÃO ENERGÉTICA}

Em 2019 o Programa das Naçōes Unidas para o Meio Ambiente divulgou o Primeiro Relatório Global sobre o Estado de Direito Ecológico, que avaliou o estado da arte das instituiçóes e políticas públicas ambientais, estabelecendo novos desafios para a preservaçâo e melhoria das condiçóes do planeta. Neste documento, uma das recomendaçôes centrais se deu na adoçâo de processos de eficiência energética, visando a reduçâo do consumo, bem como o aumento substancial da participaçăo de energias renováveis na matriz energética global, em consonância com os Objetivos do Desenvolvimento Sustentável (ONU, 2019).

Desde os primeiros alertas acerca do entendimento humano sobre a "crise do planeta" (STONE, 2017, p. 224), que já descreviam o cenário atual de impactos globais e a necessidade de mudanças na sociedade e na consciência sobre o ambiente, diversos sâo os desafios enfrentados e as soluçōes que vêm sendo intentadas. Ainda assim, nas últimas três décadas do século XX, a escassez de recursos e degradaçấo ambiental 
seguiram sendo dilemas globais, e a situaçăo tem até piorado à medida que graves desafios ambientais adicionais vêm à tona (MIKOSA, 2017, p. 261).

Um exemplo desta situaçâo pode ser observado na China, cujo governo está promovendo a reduçáo do uso do carvâo mineral e investindo na extraçáo de gás de xisto, trazendo consequências ambientais novas e ainda desconhecidas e demonstrando que muitas vezes a adoçăo de inovaçóes e avanços tecnológicos é acompanhada de riscos ainda nâo contemplados pela legislaçăo ambiental existente (ONU, 2019, p. 42).

Uma transiçăo para fontes de energia renováveis e limpas năo é exigência exclusivamente ambiental ou ecológica, mas se coloca como soluçâo para uma crise multidimensional (ecológica, econômica e social). Essa se verifica tanto pela dimensăo da pobreza e das privaçôes em escala mundial, desigualdade, discriminaçâo - e deterioraçấo ecológica - quanto pela crise do sistema econômico dominante, cuja superaçăo exige mudanças substanciais na organizaçăo econômica e social (CARPINTERO; REICHMANN, 2013, p. 46). Ademais, ao longo da evoluçăo da civilizaçăo humana, a transiçâo de um sistema socioeconômico a outro sempre esteve caracterizada pelo aumento da utilizaçăo dos recursos naturais, o que torna ainda mais preocupante o cenário presente, que é justamente o contrário, de restriçáo do uso de recursos e da capacidade da natureza para absorver os resíduos e impactos da açăo humana (CARPINTERO; REICHMANN, 2013, p. 51-52).

Some-se a isso a crise energética que se manifesta tanto pela "aceleraçâo das mudanças climáticas induzidas pelo funcionamento socioeconômico de uma espécie humana que se apoia basicamente na queima de combustíveis fósseis" quanto pela constataçâo do 'peak oil' (reconhecido por organismos internacionais e indicando o início da fase descendente da extraçaáo a nível mundial), o que coloca a sociedade frente à escassez energética futura e evidencia "o início do fim de uma era econômica caracterizada pela energia barata" (CARPINTERO; REICHMANN, 2013, p. 47).

Nesse cenário, o Brasil destaca-se mundialmente. Bermann (2012, p. 18) analisou "a dependência de combustíveis fósseis e o desafio da transiçâo para energias renováveis" indicando que o Brasil já se encontra em uma condiçăo particular e vantajosa de participaçăo de fontes renováveis na matriz energética nessa transiçăo para fontes energéticas renováveis:

o fato de mais de $3 / 4$ da energia elétrica no Brasil ser produzida a partir das águas (hidreletricidade), em conjunto com a biomassa (cogeraçăo a partir do bagaço da cana-de-açúcar e em menor medida, do gás metano biológico obtido nos aterros), confere ao país uma singular participaçăo das energias renováveis em relaçâo ao contexto internacional [...]

Em termos energéticos, a proporçăo de energias renováveis no Brasil é de 42,9 \%, contra apenas $14 \%$ na média mundial, mas quando se fala em matriz elétrica a situaçăo brasileira é ainda melhor. A matriz elétrica brasileira possui significativa participaçăo de fontes hidráulicas (65,2\%) em comparaçăo à média mundial (16,6\%), além da significativa participaçăo da biomassa: 
Figura 1: Matriz Elétrica Mundial 2017

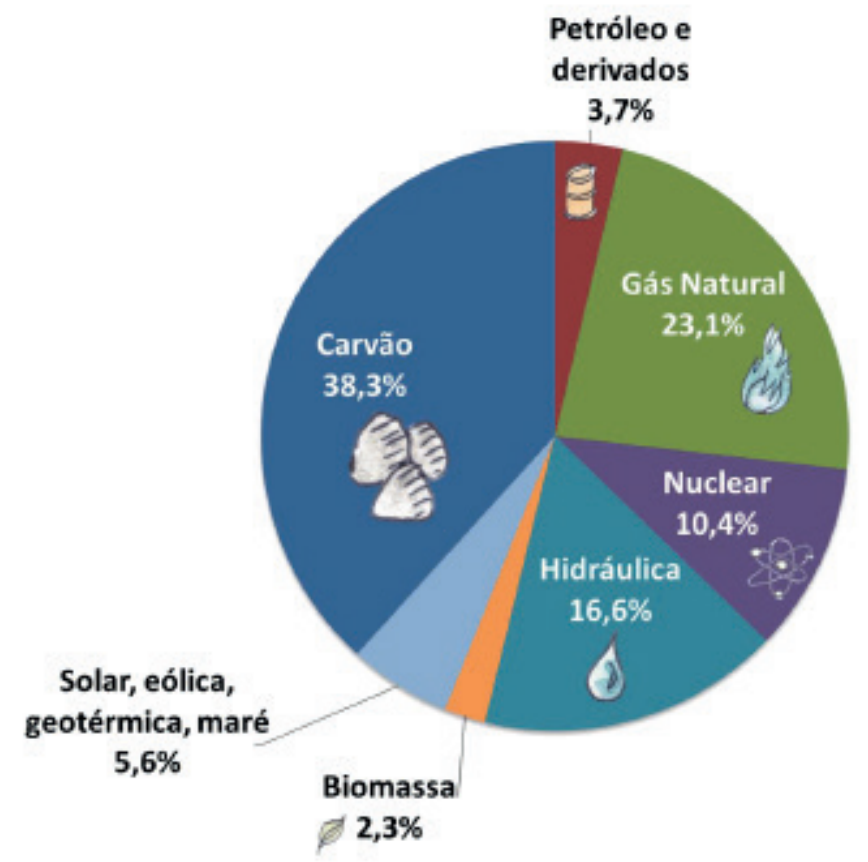

Fonte: IEA, 2018.

Figura 2: Matriz Elétrica Brasileira 2017

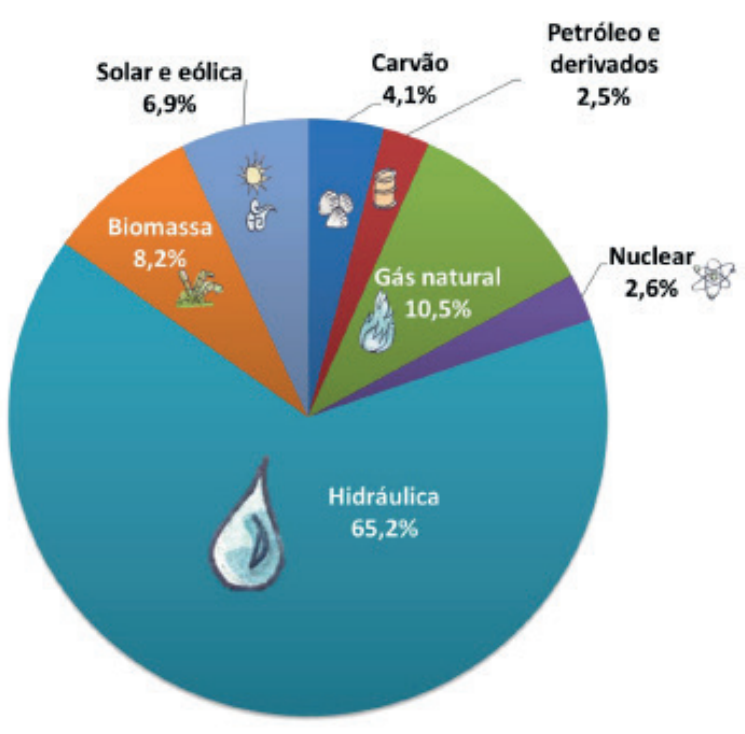

Fonte: BEN, 2018.

Referida característica reduz drasticamente a dependência do Brasil de combustíveis fósseis e, em especial, do carvăo mineral, vantagem qualitativa que torna a matriz elétrica brasileira mais limpa e livre de impactos indesejáveis ao meio ambiente e à 
sociedade. Com efeito, as iniciativas para a reduçăo do uso do carvâo mineral năo se justificam somente na reduçâo de emissōes de gases de efeito estufa, mas também é "dirigida à poluiçáo de mercúrio decorrente da queima do carvấo mineral para geraçáo de energia elétrica, questâo que envolve diversos setores e jurisdiçóes" (ONU, 2019, p. 68).

É o caso da poluiçăo transfronteiriça. O carvâo mineral é responsável pelos principais poluentes atmosféricos, cabendo citar os óxidos de enxofre e compostos sulfurosos e óxidos de nitrogênio, que provocam impactos gravíssimos e imprevisíveis, servindo de exemplo a acidificaçâo de lagos no Canadá na década de 1980, causada por termelétricas a carvâo nos Estados Unidos (ARBOUR et al, 2016). Como decorrência deste episódio, nos anos seguintes países do hemisfério norte (Comunidade Europeia, Estados Unidos, Canadá) firmaram acordos para a reduçáo do uso de termelétricas e emissóes da queima de carvâo, obtendo reduçóes que chegaram a 70\% (ARBOUR et al, 2016).

Com maiores restriçóes no Norte Global, tecnologias obsoletas passaram a ser deslocadas para países do hemisfério sul, fenômeno conhecido como deslocalizaçăo dos impactos ambientais negativos (ALIER, 2007). As consequências desta transferência de tecnologias obsoletas e poluentes sáo evidentes. O Estado de Santa Catarina ainda hoje experimenta estes impactos, com 50\% de seus recursos hídricos poluídos, sendo que na sua regiâo sul "a poluiçâo da mineraçăo de carvâo é o principal fator poluidor das águas" (CHAVES, 2017, p. 10/11).

Danos à saúde humana também foram estudados na Zona Carbonífera do Sul de Santa Catarina. Ávila Junior et al. (2009) constataram que habitantes das proximidades da mina estâo em risco de saúde em relaçâo a doenças relacionadas à poeira da mineraçăo de carvăo. Conforme descrevem, as partículas de poluiçăo do ar causam aumento na morbidade e mortalidade relatadas em estudos epidemiológicos. Segundo os autores, o excesso de exposiçâo ocupacional a metais, particularmente na mineraçâo, é considerado das principais causas de câncer. Os resultados obtidos indicam que pessoas vivendo nas proximidades da área de mineraçâo de carvăo também estăo enfrentando estresse oxidativo e risco de doenças relacionadas (ÁVILA JUNIOR et al., 2009).

A queima do carvâo mineral em usinas térmicas de energia foi examinada por Possamai et al (2010), como geradora de dois tipos de cinzas, as partículas ultrafinas e as cinzas ou material particulado, considerado mais prejudicial, que expóe os seres humanos a doenças ocupacionais graves. Conforme os autores apontam, estudos vêm sugerindo que a poluiçáo do ar pode ser responsável pelo aumento do risco de câncer de pulmáo e doenças cardiovasculares, entre outros, ligando esses riscos à exposiçâo ao material particulado. A inalaçăo de poeira por longos períodos emitida pela mineraçâo de carvăo e queima do carvăo gera muitas patologias, incluindo bronquite, asma, câncer, fibrose, enfisema e pneumoconiose, desencadeando um processo inflamatório crônico.

Estudos realizados nos Estados Unidos também apontaram uma série de doenças causadas pela inalaçăo de poeira de minas de carvấo. O recente reconhecimento de pneumoconiose rapidamente progressiva em menores de idade aumentou o senso de urgência e a necessidade de vigilância na pesquisa médica, diagnóstico clínico e prevençâo de exposiçăo, entretanto, o espectro de doenças pulmonares associadas à exposiçăo à poeira de minas de carvâo é mais amplo do que geralmente reconhecido e inclui ainda silicose e fibrose difusa relacionada à poeira (PETSONK et al 2013). 
Outra importante fonte geradora de impacto ambiental a partir do processamento do carvăo mineral está relacionada à formaçăo de estéreis e rejeitos ricos em dissulfeto de ferro (FeS2), conhecido como pirita, que se oxidam na presença do ar, da água e decorrente da açăo de algumas bactérias, gerando drenagens ácidas de minas, com acentuada toxicidade aguda sobre organismos vivos quando expostos a diferentes concentraçóes de drenagem ácida da mina e metais pesados (TORREZANI; OLIVEIRA, 2013).

Em recente trabalho no Estado de Santa Catarina, Menezes et al (2019, p. 7) apontam que os impactos gerados pela mineraçăo de carvâo sâo de grande magnitude, e que a extraçấo de carvâo a montante de recursos hídricos "tem provocado alteraçóes físicas, químicas e biológicas nos ecossistemas locais, comprometendo de forma severa os recursos hídricos, o solo e a biota". Os autores ainda destacam a persistência desses impactos ambientais negativos: "Os recursos hídricos continuam seriamente comprometidos e, nesse contexto, tanto em termos de perdas da biodiversidade e contaminaçăo do solo, incluindo os sedimentos aquáticos". (MENEZES, 2019, p. 11)

Os impactos ambientais mencionados contribuem para reduçâo da biodiversidade, a extinçáo de espécies, além do agravamento da crise ecológica que afeta todas as formas de vida, inclusive a humana. Brack (2011) alerta que essa transgressăo dos limites de capacidade de suporte dos ecossistemas compromete sua capacidade de resiliência, sujeitando-os a impactos irreversíveis, de longo prazo e/ou permanentes. A intervençăo humana vem causando perda significativa da biodiversidade no planeta, fragmentaçăo de habitats e expansâo de espécies exóticas invasoras, fatores que afetam a integridade dos processos ecológicos essenciais, de modo que, "na atualidade, as áreas naturais estâo tornando-se cada vez mais impactadas, com maior fragilidade no que se refere a sua capacidade particular de resiliência" (BRACK, 2011, p. 149).

A resiliência - humana e ecológica - é vista por William Ophuls (2017) como uma proteçâo contra as inevitáveis pandemias globais decorrentes da escassez ecológica, o que demandará da sociedade "uma transiçấo do Titanic para uma embarcaçăo menor, mais simples e mais modesta" (OPHULS, 2017, p. 191 e 237). Nesse cenário, além da perda de bens e recursos ecossistêmicos e a dificuldade de controlar o déficit ecológico, as mudanças climáticas têm o papel central de evidenciar uma necessidade de âmbito global, sendo "indiscutível que o tema das mudanças climáticas e da destruiçâo dos ecossistemas identifica uma emergência" (CARDUCCI, 2016, p. 53).

Paulo Artaxo (2019, p. 45) elenca os processos causadores da emissâo de gases de efeito estufa iniciando a enumeraçâo pela "queima de combustíveis fósseis", seguida do desflorestamento de florestas tropicais, atividades industriais, desenvolvimento da agricultura e outros fatores. É relevante destacar o aumento da taxa de desmatamento na Amazônia desde o ano de 2013. Paulo Brack (2019) associa esse fato ao novo Código Florestal aprovado em 2012, dotado de regras menos protetivas, e a incêndios criminosos relacionados ao avanço da indústria ilegal de madeira, garimpo, minérios, além do agronegócio, representado principalmente pela pecuária e pela monocultura da soja.

A associaçâo da produçâo agrícola com as mudanças climáticas também é estabelecida pela ONU nas conclusōes do relatório do relator especial sobre direito à alimentaçâo do Conselho de Direitos Humanos, que vê no modelo de bases biológicas, em contraposiçâao às bases químicas e de uso de maquinário intensivo da agricultura "tradicional", uma saída vantajosa à qualidade da alimentaçăo e com reflexo positivo 
no clima e na qualidade ambiental do planeta (ONU, 2017, p. 23).

Nesse caminho, Carpintero e Reichmann (2013) propōem uma transiçâo através da organizaçấo econômica e social diferente da atual, com a adoçăo de princípios de sustentabilidade, mediante o uso fontes energéticas renováveis, processos de ciclo fechado, suficiência e redistribuiçâo democrática e observância ao Princípio da Precauçăo, no caminho de uma necessária transiçăo "em termos socioeconômicos e socioecológicos que coloque as necessidades da espécie humana e dos demais seres vivos e seu bem estar no centro da discussāo" (CARPINTERO; REICHMANN 2013, p. 70).

Em sentido oposto à vocaçâo brasileira de desenvolvimento das energias renováveis na matriz energética, e da tendência global nesse sentido, no Estado do Rio Grande do Sul reacendeu-se o interesse na extraçăo de carvăo mineral através de um projeto privado denominado 'Mina Guaiba'. O mencionado projeto, proposto para ser a maior mina de carvâo a céu aberto do Brasil, tem como suas justificativas o baixo custo de extraçấo, dado o aproveitamento de maquinário utilizado pela empresa em outras atividades, e a facilidade do beneficiamento do minério ante a abundância de água no local (EIA/RIMA Mina Guaiba, 2018, p. 3-21/3-35).

Os impactos socioambientais do uso desse recurso hídrico sobre as populaçôes abastecidas pelo manancial nâo foi avaliada na escolha da localizaçáo do projeto proposto, e sequer foram apresentadas as alternativas locacionais ao projeto - exigidas pela legislaçáo ambiental - a pretexto de uma suposta "rigidez locacional" decorrente da autorizaçăo fornecida pela agência reguladora de mineraçăo. Conforme consta do referido estudo, a análise das alternativas locacionais nâo foi apresentada devido "à rigidez locacional do minério, o que restringe significativamente a escolha de alternativas ao local da mina" (EIA/RIMA Mina Guaiba, 2018, p. 4-1), apesar de próprio estudo reconhecer que a empresa proponente possui outras cinco jazidas passíveis de exploraçăo em outras regiôes do Estado.

Para lidar com situaçôes como a exposta, que se relacionam com as mudanças climáticas e o bem estar das populaçóes, Aragăo (2017) defende que o Estado de Direito deve estar atento aos limites do planeta e engajado em resultados eficazes na prevençăo e melhoria da qualidade ambiental: "manter a abordagem jurídica anterior, correndo o risco de ultrapassar os limites do Planeta será considerado contrário ao Direito" (ARAGÄO 2017, p. 35). No mesmo sentido, Leite et al (2017, p. 58-59) destacam que "a modificaçáo dos sistemas e do comportamento humano năo se revelou suficiente para conter a devastaçăo do Planeta", de modo que as mudanças climáticas apontam para "o agravamento da referida crise ambiental e da insuficiência do Estado de Direito Ambiental para controlá-la" (MELO et al., 2018, p. 22).

Decisôes que que se projetam sobre o bem estar de comunidades tanto a nível local como global, com impactos à saúde e aumento da emissăo de gases de efeito estufa com agravamento das mudanças climáticas, demandam a adoçâo de medidas e decisóes fundadas na "percepçáo de que a defesa e a preservaçăo do meio ambiente săo o suporte da vida no Planeta" (ALBUQUERQUE, 2009, p. 120). 


\section{O CARVÃO MINERAL NO CONTEXTO DAS MUDANÇAS CLIMÁTICAS E DA LITIGÂNCIA CLIMÁTICA ESTRATÉGICA}

Em uma perspectiva histórica, a locuçāo “justiça ambiental" identifica dois elementos do movimento ambiental: o movimento contra o racismo ambiental e aquele que se opóe à contaminaçâo tóxica. Porém, existe um amplo número de causas de ativismo em justiça ambiental que únem pautas territoriais, ambientais e sociais (SCHLOSBERG, 2007, p. 46).

Foi na década de 1960, nos Estados Unidos, que surge o movimento de justiça ambiental. Nessa localidade, tal movimento estava associado à luta por direitos políticos e civis, a partir do momento em que os movimentos sociais alcançam a percepçấo de que a populaçâo mais vulnerável em termos de direitos econômicos e sociais, também é a mais vulnerável quando se trata de riscos ambientais. O movimento iniciou-se, em âmbito nacional, por meio dos sindicatos ligados à indústria química, na medida que ocorre a constataçăo da relevância do movimento com os novos problemas ambientais enfrentados pelo Brasil, especialmente no que se refere aos riscos decorrentes do processo de industrializaçăo desse setor.

Assim, a definiçâo de meio ambiente dos movimentos por justiça ambiental se afasta do conceito puramente focado na conservaçâo (wilderness) e na ideia de áreas intocadas e isoladas, uma visăo elitista e excludente propagada por grandes organizaçôes năo governamentais (SCHLOSBERG, 2014, p. 360).

A noçăo de meio ambiente passa a ser entăo o local onde as pessoas vivem, trabalham e realizam seu lazer, tendo como foco os riscos e ameaças à vida diária, sem excluir a preocupaçāo também com o ambiente nâo humano. Adota a concepçăo indígena de relaçăo entre os humanos e a natureza năo humana, formando um conceito mais amplo de meio ambiente que se dirige desde a proteçâo dos espaços de parques e praças ao respeito às práticas culturais e soberania de povos indígenas, passando pela proteçăo da flora e fauna.

Esta noçâo ampla de meio ambiente focada na relaçâo entre sadia qualidade de vida e o mundo natural ilustra como a evoluçăo para a preocupaçăo com a mudança climática náo é algo inesperado neste contexto (SCHLOSBERG, 2014, p. 360). Além disso, a justiça ambiental sempre focou em como a injustiça é construída, tendo destaque demandas por participaçăo e justiça procedimental, e a exclusâo do processo de participaçâo, que acaba permitindo a distribuiçâo desigual e o contexto de injustiça em comunidades vulneráveis.

Esse quadro se expandiu para outros tópicos e países e para questōes globais. 0 crescimento horizontal se deu com a ampliaçâo tópica com questóes relacionadas à qualidade de vida, e com a ampliaçấo geográfica do quadro da justiça ambiental a países por todo o mundo. $O$ crescimento vertical se deu com a inserçấo de questôes globais, como o comércio internacional de produtos tóxicos e a mudança climática (SCHLOSBERG, 2014, p. 362).

Em 2001 foi criado o Environmental Justice and Climate Change Initiative como resultado do primeiro Climate Justice Summit realizado durante a COP6 da Convençáo Quadro das Naçôes Unidas sobre Mudança Climática. Em 2002 foram produzidos 10 princípios das mudanças climáticas, com foco na reduçăo de emissôes e uso de 
combustíveis fósseis, proteçăo de comunidades vulneráveis, garantia de uma transiçăo justa para energias renováveis, participaçăo e inclusâo da comunidade, adoçáo de medidas frente a incertezas, justiça intergeracional e liderança dos EUA na questáo global da mudança climática. Posteriormente um relatório apontou que os impactos da mudança climática recaem desproporcionalmente sobre populaçôes já vulneráveis. Em 2005 o furacăo Katrina solidificou a confluência do quadro da justiça ambiental com a questáo da mudança climática (SCHLOSBERG, 2014, p. 362).

O furacâo Katrina evidenciou as injustiças pré-existentes na cidade de New Orleans, como a pobreza, a segregaçâo racial, as casas construídas abaixo de um padrâo de qualidade e o sistema de educaçăo precário. Ficou claro a insuficiência de recursos da comunidade, de forma que as minorias já estavam despreparadas no que concerne a questóes de infraestrutura e padróes de vida antes mesmo da ocorrência do fenômeno natural. Ademais, essas comunidades foram menos atendidas após o furacâo, uma vez que receberam menos informaçóes, ajuda governamental e empréstimos, além de uma contínua discriminaçâo (BULLARD; WRIGHT, 2009).

É relevante evidenciar, que a justiça ambiental impactou outros movimentos, visto que esses desenvolveram demandas por uma justiça voltada ao clima. Assim, pode-se dizer que a justiça ambiental năo foca apenas nas emissōes, mas também nos seus impactos e no custo de energia, de modo que políticas devam abordar as consequências desiguais com algum tipo de compensaçâo (SCHLOSBERG, 2014, p. 364).

Nesse contexto, consoante Schlosberg (2014, p. 365), o argumento central de uma abordagem de responsabilidade histórica é a de que há certos Estados que fizeram com que nos encontrássemos em nosso dilema atual de mudanças climáticas. Esses Estados precisariam agora ter a responsabilidade primária pelos resultados de suas açôes, e assim, deveriam pagar pelos custos causadas por essas transgressōes passadas. Tal ideia é defendida por países menos desenvolvidos, os quais somente enxergam vulnerabilidade em seus futuros, enquanto os países industrializados continuam a enriquecer com suas práticas destrutivas.

A abordagem de responsabilidade histórica é também um argumento comum para as comunidades no movimento de justiça ambiental, no qual a temática da compensaçáo por dano ambiental é recorrente, dado que um dos principais direitos originais da justiça ambiental é a completa compensaçâo e reparaçâo por danos (SCHLOSBERG,2014, p. 365).

Uma das principais áreas de foco da justiça ambiental tem sido o potencial de um vasto número de desigualdades criadas ou aumentadas pelas mudanças climáticas. Nesse diapasăo, a adaptaçâo tem sido abordada como uma maneira de ligar justiça ambiental, justiça climática e justiça social aos mais vulneráveis. Adaptaçăo também é vista como uma oportunidade de abordar um amplo apanhado de questôes de justiça social mais genericamente. Ao abordar adaptaçăo, a justiça ambiental pode vir a oferecer um caminho para o desenvolvimento de potenciais alianças com grupos mais conhecidos focados na política nacional ou global (SCHLOSBERG, 2014, p, 368).

Assim como a justiça ambiental no geral, Schlosberg (2014, p. 369) destaca que um conceito de justiça baseado no clima que endereça apenas adaptaçăo significa olhar além das concepçóes de justiça distributiva. Enquanto a desigualdade é central, o foco da justiça ambiental na adaptaçăo é inteiramente associado com questôes particulares 
de participaçăo, impactos culturais e nas capacidades que as comunidades precisam para funcionar.

Percebe-se que a epistemologia tradicional (cartesiana), o paradigma simplista, o direito e Estado moderno (intrinsecamente antropocêntricos) resultaram na exploraçâo ambiental que ocasionou uma dívida histórica dos países "desenvolvidos" em relaçâo aos "nâo desenvolvidos". Isso resultou em consequências catastróficas ao clima no Planeta e em processos de compensaçâo e adaptaçăo em que os mencionados países devem agora se envolver.

Quanto ao emprego de carvâo como prática destrutiva, destaca-se que no âmbito da geraçấo de eletricidade houve um significativo crescimento no Brasil dado o aumento da geraçăo termelétrica a combustível fóssil e a queda de geraçăo de energia em hidrelétricas (ARTAXO; RODRIGUEZ, 2019, p. 47). Atualmente, a comunidade humana emite cerca de 42 Giga toneladas (Gt) de CO2 por ano em decorrência da queima de combustíveis fósseis e desmatamento, sendo que $90 \%$ desse total provém da queima de combustíveis fósseis. O dióxido de carbono (CO2) é um dos gases que absorvem a radiaçăo infravermelha e retornam para a superfície terrestre, aquecendo-a (ARTAXO; RODRIGUEZ, 2019, p. 43).

Em consequência disso, o clima de nosso país já está sendo afetado de maneira significativa pelo aquecimento global. Na Regiăo Nordeste, do período de 1981-2010, a temperatura já se elevou dois graus centígrados e a chuva já foi reduzida em $30 \%$. Há incertezas nas previsôes climáticas ao longo deste século. As previsōes existentes para o período de 2071 a 2099, revelam a possibilidade da Regiâo Centro-Oeste aquecer sete graus e a Nordeste aproximadamente cinco graus (ARTAXO; RODRIGUEZ, 2019, p. 47-48).

Voltando-se à jurisprudência existente de litígios climáticos, Setzer, Cunha e Fabbri (2019, p. 8) classificam essa em quatro categorias. A primeira questiona as emissôes de GEE de autorizaçóes ou licenças, bem como exige a inclusăo da componente climática nos estudos de impacto ambiental. É o caso das usinas de carvâo localizadas na Austrália (SETZER; CUNHA; FABBRI, 2019, p. 8). A segunda demanda é face governos e empresas a respeito de informaçóes sobre emissóes, medidas de adaptaçăo, investimentos feitos e consideraçăo do risco climático em balanços comerciais. Um exemplo é a demanda contra o governo alemăo visando informaçăo sobre impacto às mudanças climáticas associadas a créditos de exportaçâo.

A terceira compreende litígios que requerem novas normas jurídicas ou o detalhamento das existentes e visam questionar ou exigir a implementaçăo de política ou lei climática. Um exemplo seria o emblemático caso Urgenda versus Holanda e Massachussetts versus EPA (SETZER; CUNHA; FABBRI, 2019). A quarta abarca a temática de responsabilizaçấo por danos materiais ou morais por eventos associados às mudanças climáticas. O exemplo é do litígio de Saula Lhuya contra a empresa alemá RWE, por danos nos andes peruanos.

Dada a relevância do caso Urgenda versus Holanda como exemplo de litígio climático, faz-se necessário discorrer brevemente acerca do mesmo. Um grupo ambiental holandês, a Fundaçăo Urgenda, e 900 cidadâos holandeses processaram o governo holandês a fim de requerer que mais seja feito para impedir a mudança climática global. O Tribunal de Haia ordenou que o Estado holandês limite as emissōes de gases de 
efeito estufa a pelo menos $25 \%$ abaixo dos níveis de 1990 até 2020 , considerando que a promessa existente do governo de reduzir as emissóes em $17 \%$ é insuficiente para atender à justa contribuiçâo do Estado para a meta da ONU de manter os aumentos globais de temperatura dentro de dois graus Celsius acima das condiçóes pré-industriais. O Tribunal concluiu que o Estado tem o dever de adotar medidas de mitigaçấo das mudanças climáticas devido à severidade das conseqüências das mudanças climáticas e ao grande risco de que as mudanças climáticas ocorram.

Esta é a primeira decisâo de qualquer tribunal do mundo requerendo que um Estado limite as emissóes de gases de efeito estufa por outras razóes que nâo os mandatos legais. O Estado da Holanda, em seu recurso à decisăo final do Tribunal de Haia, assevera que o requerimento de reduçăo da emissăo de gases de efeito estufa năo é admissível, uma vez que: 1. a ordem equivale a uma ordem de criaçáo de legislaçáo, o que segundo a jurisprudência da Suprema Corte da Holanda, năo pode ser exigido pelo Poder Judiciário; 2. năo cabe ao Poder Judiciário fazer as consideraçōes políticas necessárias para uma decisăo relativa à reduçăo da emissăo de gases de efeito estufa (HOLANDA, 2019).

Na decisāo do Supremo Tribunal da Holanda, este estabeleceu: "Se o governo é obrigado a fazer algo, pode ser ordenado pelos tribunais, como qualquer um pode ser, a pedido da parte autorizada (Artigo 3: 296 DCC). Essa é uma regra fundamental da democracia constitucional, consagrada em nossa ordem jurídica." ${ }^{4}$ e "[...] a Constituiçáo holandesa estipula que os tribunais civis têm jurisdiçăo sobre todas as reivindicaçóes, para que eles sempre possam conceder proteçâo legal se nenhuma proteçăo legal for oferecida por outro tribunal."5 (HOLANDA, 2019, p. 40). No caso, destaca-se a importância da atuaçăo do Poder Judiciário, a qual, como pode-se vislumbrar, foi evidenciada no mérito da decisăo mencionada.

Um dos principais objetivos de grande parte dos litígios sobre mudança climática tem sido estimular a regulamentaçăo de emissóes de gases de efeito estufa e, por outro lado, contribuir para a mitigaçâo de mudanças climáticas. O caso da Suprema Corte dos EUA de Massachusetts versus EPA é o principal exemplo desse tipo de litígio (PEEL; OSOFSKY, 2015, p. 55).

Porém, conforme Peel e Osofsky (2015, p. 109), a elaboraçăo de políticas e a litigância voltam-se cada vez mais para as questóes de adaptaçăo à medida que as falhas na mitigaçáo continuam amplificando os riscos dos impactos e os eventos climáticos severos aumentam a conscientizaçăo do público sobre esses efeitos. Enquanto a mitigação considera como limitar as mudanças humanas ao clima, a adaptaçăo refere-se às mudanças feitas para melhor responder às mudanças climáticas presentes ou futuras, reduzindo assim os danos ou aproveitando as oportunidades (ESTADOS UNIDOS, 2009).

Segundo Peel e Osofsky (2015, p. 10), há três razōes pelas quais os litígios sobre mudanças climáticas săo importantes como um componente do sistema geral de

4 No original: "If the government is obliged to do something, it may be ordered to do so by the courts, as anyone may be, at the request of the entitled party (Article 3:296 DCC). This is a fundamental rule of constitutional democracy, which has been enshrined in our legal order." (HOLANDA, 2019, p. 40).

5 No original: "[...] the Dutch Constitution stipulates that civil courts have jurisdiction over all claims, so that they can always grant legal protection if no legal protection is offered by another court." (HOLANDA, 2019, p. 40). 
governança climática. A primeira concentra-se na falha dos esforços regulatórios internacionais, o que aumenta a dependência em relaçăo a soluçóes regulatórias nacionais para as quais os litígios podem contribuir. A segunda se resume pela utilidade da litigância em conectar as diferentes escalas em que a governança climática opera e os muitos atores que envolve. Por fim, a terceira razăo é a eficácia da litigância em gerar a cumulatividade de inúmeras decisōes em pequena escala (das quais a mitigaçâo e os resultados adaptativos dependem), muitas das quais săo submetidas a tribunais e através das quais a litigância pode desempenhar um papel de modelagem eficaz.

Por conseguinte, assevera-se que a litigância climática se estabelece como as formas judiciais e administrativas que possibilitam o manejo de demandas destinadas à mitigaçâo das emissóes, medidas de adaptabilidade das populaçóes vulneráveis, reparaçôes e gestâo de riscos, associados a quaisquer das fases de extraçăo, produçấo e distribuiçăo de bens e energia relacionados à emissâo de gases de efeito estufa (SETZER; CUNHA; FABBRI, 2019). Como o regime de tratados internacionais continua falhando em obter compromissos vinculativos dos Estados-naçâo adequados para evitar sérios riscos de impactos, a litigância climática apresenta extrema relevância como ferramenta de auxílio à regulaçâo neste âmbito.

\section{CONCLUSÕES}

A partir desta pesquisa, procurou-se analisar a transiçăo energética com foco nas fontes renováveis e no abandono dos combustíveis fósseis, no contexto da crise de caráter econômico, social e ecológico que a humanidade hoje atravessa. A hipótese aventada foi que a transiçấo da matriz energética brasileira tem no uso da biomassa vantagens comparativas com relaçáo aos demais países, com benefícios do ponto de vista dos reduzidos impactos ao meio ambiente, ao clima e às populaçóes humanas, se comparada às fontes provenientes de combustíveis fósseis.

Na primeira seçăo foi analisada a situaçăo geral da matriz energética brasileira e as possibilidades de transiçăo rumo ao incremento das energias renováveis, bem como a utilizaçâo do carvâo mineral no contexto da crise de caráter multidimensional. $\mathrm{Na}$ segunda seçăo, este contexto foi examinado com foco nas questóes associadas à justiça ambiental e à emergência de casos de litigância climática, voltados à mitigaçăo, adaptaçăo, reparaçấo e gestăo de riscos.

O foco na matriz energética renovável, que no Brasil encontra campo fértil na biomassa da cana-de-açúcar e outras opçōes, vislumbra-se como uma forma sustentável de transiçăo da matriz energética rumo a fontes renováveis e mais limpas, exercendo um papel importante na mitigaçâo das emissôes de gases de efeito estufa.

Os dados analisados indicam que as linhas argumentativas da justiça climática e as estratégias de litigância climática sâo aplicáveis à extraçâo de carvâo pretendida, em todas as categorias de litígios, de forma preventiva para perseguir a mitigaçăo das emissôes a fim de reduzir os riscos da atividade de extraçăo às populaçóes localmente atingidas por meio da limitaçăo das mudanças humanas ao clima. Nesse âmbito, o fortalecimento dos direitos à informaçâo, participaçâo na tomada de decisâo e acesso à justiça - formas procedimentais típicas da justiça ambiental - naturalmente encontram relevância igual ou maior nos conflitos socioambientais de repercussăo climática. 
No caso último da consecuçăo da atividade, têm aplicabilidade as estratégias de litígios climáticos reparatórios de danos e de exigência de medidas de adaptaçâo que visem reduzir a vulnerabilidade das populaçóes locais, conforme os fundamentos argumentativos da justiça climática e os precedentes de litigância já existentes, fazendo recair ao empreendedor a responsabilidade tanto dos danos à saúde da populaçăo e aos bens ambientais degradados pela atividade quanto dos custos das medidas de adaptaçăo necessárias para fazer frente às consequências da aceleraçăo da mudança do clima.

\section{REFERÊNCIAS}

ALBUQUERQUE, Letícia. Conflitos socioambientais na Zona Costeira Catarinense: estudo de caso da Barra do Camacho/SC. 2009.Tese (Doutorado em Direito) - Universidade Federal de Santa Catarina, Centro de Ciências Jurídicas, Universidade Federal de Santa Catarina, Florianópolis, 2009. Disponível em: https://repositorio.ufsc.br/bitstream/handle/123456789/92868/278416.pdf? sequence=1. Acesso em 05 abr. 2019.

ALIER, Joan Martinez. 0 ecologismo dos pobres: conflitos ambientais e linguagens. Săo Paulo: Contexto, 2007. 378 p.

ARAGĀO, Alexandra. O Estado de Direito Ecológico no Antropoceno e os Limites do Planeta. In: LEITE, José Rubens Morato (org.); DINNEBIER, Flávia França (org). Estado de Direito Ecológico: conceito, conteúdo e novas dimensôes para a proteçáo da natureza. Sáo Paulo: Inst. O direito por um Planeta Verde, 2017, p. 20-37. E-book. Disponível em: http://www.planetaverde.org/biblioteca-virtual/e-books/p:2. Acesso em 05 abr. 2019.

ARTAXO, Paulo; RODRIGUES, Délcio. As bases científicas das mudanças climáticas. In: SETZER, Joana. et al. Litigância Climática: novas fronteiras para o Direito Ambiental no Brasil. Săo Paulo: Thomson Reuters Brasil, 2019.

ARBOUR, J-M.; LAVALLÉE, S.; SOHNLE, J.; TRUDEAU, H. Droit International de L'environnment. 3. ${ }^{a}$ Ediçăo. Montréal: Yvon Blais/Thomson Reuters, 2016. 1527 p.

BERMANN, Célio. Setor Elétrico Brasileiro e a Sustentabilidade no Século 21: Oportunidades e Desafios. Brasília: Rios Internacionais, 2012.

BRACK, Paulo. Crise da biodiversidade, ainda distante da economia. Ciência e Ambiente, n. 42, p. 147-162, janeiro/junho 2011. Disponível em: http://inga.org.br/sem-categoria/ crise-da-biodiversidade-ainda-distante-da-economia/. Acesso em: 13 out. 2019.

BRACK, Paulo. As queimadas na Amazônia e o alerta do colapso do modelo de ocupaçăo e de gestăo ambiental. Revista Textual, v. 1, n. 27, p. 37-42, out. 2019. Disponível em: https:// www.ufrgs.br/biociencias/index.php/noticias/836-leitura-ensaio-na-revista-textual-revista-textual-sinpro-as-queimadas-na-amazonia-e-o-alerta-do-colapso-do-modelo-de-ocupacao-e-de-gestao-ambiental-com-prof-paulo-brack. Acesso em: 13 out. 2019. 
BULLARD RD; WRIGHT B. Race, Place, and Environmental Justice After Hurricane Katrina: Struggles to Reclaim, Rebuild, and Revitalize New Orleans and the Gulf Coast. Boulder, Nova Iorque: Westview Press; 2009.

CARDUCCI, Michele. Il "deficit ecologico" del pianeta come problema di "politica costituzionale" - Parte Prima. Revista Jurídica da FURB, v. 20, n. 42, p. 37-66, maio/ago 2016. Disponível em: http://proxy.furb.br/ojs/index.php/juridica/article/view/5987. Acesso em: 26 jul. 2019.

CARPINTERO, Óscar.; REICHMANN, Jorge. Pensar la transición: enseñanzas y estrategias económico-ecológicas. Revista de Economía Crítica, n. 16, p. 45-107, jul/dez 2013. Disponível em: http://www.economiacritica.net/?p=2677. Acesso em: 26 jul. 2019.

CHAVES, Tiago Fernando. Uma análise dos principais impactos ambientais verificados no estado de Santa Catarina. Revista Gestăo \& Sustentabilidade Ambiental, v. 5, n. 2, p. 611-634, out. 2016/mar. 2017. Disponível em: http://www.portaldeperiodicos.unisul. br/index.php/gestao_ambiental/article/view/4198.Acesso em: 26 jul. 2019.

EIA/RIMA Mina Guaiba. Fundaçăo Estadual de Proteçăo Ambiental Henrique Luis

Roessler - RS, v. I, 2018. Disponível em: http://www.fepam.rs.gov.br/eia-mina-guaiba/ Acesso em: 26 jul. 2019.

EMPRESA DE PESQUISA ENERGÉTICA. Balanço Energético Nacional 2018: Ano base 2017. Rio de Janeiro: EPE, 2018. Disponível em: http://epe.gov.br/pt/publicacoes-dados-abertos/publicacoes/balanco-energetico-nacional-2018 Acesso em: 26 set. 2019.

ESTADOS UNIDOS. U.S. Global Change Research Program, 2009. Disponível em: <https:// nca2009.globalchange.gov/executive-summary/index.html>. Acesso em: 22 fev. 2020.

GLOBAL ENVIRONMENTAL OUTLOOK 2019. Paris: IEA, 2019. Disponível em: https:// www.iea.org/statistics/?country=WORLD\&year=2016\&category=Key\%20indicators\&indicator=TPESbySource $\&$ mode=chart $\&$ categoryBrowse=false\&dataTable=BALANCES\&showDataTable=true Acesso em: 26 set. 2019.

HOLANDA. Supremo Tribunal Federal, Divisăo Civil. Holanda versus Urgenda. Número 19/00135, 20 de dezembro de 2019. Disponível em: http://climatecasechart.com/non-us-case/urgenda-foundation-v-kingdom-of-the-netherlands/ Acesso em: 22 fev. 2020.

LEITE, J.R.M.; SILVEIRA, P.G.; BETTEGA, B. O Estado de Direito para a Natureza: fundamentos e conceitos. In.: LEITE, José Rubens Morato (org.); DINNEBIER, Flávia França (org). Estado de Direito Ecológico: Conceito, Conteúdo e Novas Dimensôes para a Proteçăo da Natureza. / Flávia França Dinnebier (Org.); José Rubens Morato (Org.); Săo Paulo: Inst. O direito por um Planeta Verde, 2017, p. 57-87. E-book .Disponível em: http:// www.planetaverde.org/biblioteca-virtual/e-books/p:2. Acesso em 05 abr. 2019. 
MELO, M.E.; BAHIA, C.M.; LEITE, J.R.M. Estado de Direito Ecológico: alicerce legal para a materialização de Justiça Ambiental e Ecológica. In: MELO, Melissa Ely (org); LEITE, José Rubens Morato (org.) Delineamentos do Direito Ecológico: Estado, Justiça, Território e Economia. Rio de Janeiro: Lumen Juris, 2018. p. 286.

MENEZES, B.F.; CENI, G.; MARTINS, M.C.; VIRTUOSO, J.C. Percepçăo de Impactos Socioambientais e a gestăo costeira: estudo de caso de uma comunidade de pescadores no litoral sul de Santa Catarina, Brasil. Revista Gestăo \& Sustentabilidade Ambiental, v. 8, n. 3, p. 457- 481, jul/set 2019. Disponível em: http://www.portaldeperiodicos.unisul. br/index.php/gestao_ambiental/article/view/6453.Acesso em: 26 set. 2019.

MIKOSA, Zaneta. Implementation of The Aarhaus Convention Trough Actio Popularis: Article 9(3) of the Aarhaus Convention and Actio Popularis. In.: JENDROŚKA, Jerzy.; BAR, Magdalena. Procedural Environmental Rights: Principle X In Theory And Practice. European Environmental Law Forum Series, volume 4. Intersentia Ltd: Cambridge, 2017. $502 \mathrm{p}$.

OPHULS, William. A vingança de Platăo: política na era da ecologia. Săo Paulo: Ediçôes Sesc Sáo Paulo, 2017. 237 p.

PEEL, Jacqueline; OSOFSKY, Hart M. Climate Change Litigation: Regulatory Pathways to Cleaner Energy. Cambridge: Cambridge University Press, 2015.

PETSONK, E. L.; ROSE, C.;COHEN, R. Coal Mine Dust Lung Disease. New Lessons from an Old Exposure. American Journal of Respiratory and Critical Care Medicine, v. 187, n. 11, p. 1178-1185, jun. 2013. Disponível em: https://www.atsjournals.org/doi/ full/10.1164/rccm.201301-0042CI. Acesso em: 02 de jul. 2019.

POSSAMAI, F.P; AVILA JÚNIOR, S, PARISOTTO, E.B, MORATELLI, A. M.; INÁCIO, D.B.; GARLET, T.R.; DAL-PIZZOL, F.; WILHELM FILHO; D. Antioxidant intervention compensates oxidative stress in blood of subjects exposed to emissions from a coal electric-power plant in South Brazil. Environmental Toxicology and Pharmacology., v. 30, p. 175-180, maio 2010. Disponível em: https://www.academia.edu/28727040/ Antioxidant_intervention_compensates_oxidative_stress_in_blood_of_subjects_exposed_

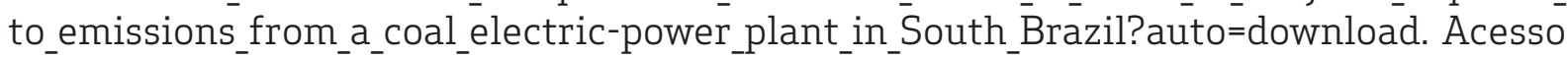
em: 02 de jul. 2019.

SCHLOSBERG, David.; COLLINS, Lisette. From environmental to climate justice: climate change and the discourse of environmental justice. WIREs Climate Change, v. 5, n. 3, p. 359-374, maio/junho 2014. Disponível em: https://onlinelibrary.wiley.com/doi/ abs/10.1002/wcc.275 .Acesso em: 02 de jul. 2019.

SCHLOSBERG, David. Defining Environmental Justice: Theories, Movements, and Nature. United Kingdom: Oxford University Press, 2007 
SETZER, Joana; CUNHA, Kamyla; FABBRI, Amália Botter. Panorama da Litigância Climática no Brasil e no Mundo. In: SETZER, J. et al. Litigância Climática: novas fronteiras para o Direito Ambiental no Brasil. Sāo Paulo: Thomson Reuters Brasil, 2019.

STONE, Christopher. Should Trees Have Standing? - Toward Legal Rights for Natural Objects.In:BOSSELMANN,Klaus;TAYLOR,Prue.EcologicalApproachestoEnvironmental Law: The International Library of Law and the Environment Series. Cheltenham: Edward Elgar Publishing, 2017, p. 450-501.

TORREZANI, Nelissa Camargo.; OLIVEIRA, Edson Fontes de. Problemas ambientais decorrentes da exploraçâo do carvâo mineral e a aplicaçăo da Ecotoxicologia aquática como ferramenta de biomonitoramento. Oecologia Australis, v. 17, n. 4, p. 509-521, dez. 2013. Disponível em: https://revistas.ufrj.br/index.php/oa/article/view/8299 Acesso em: 02 de jul. 2019.

UNITED NATIONS. GENERAL ASSEMBLY.A/HRC/34/48. Human Rights Council. Report of the Special Rapporteur on the right to food, 2017. Disponível em: http://ap.ohchr. org/documents/dpage_e.aspx?si=A/HRC/34/48. Acesso em: 21 jun. 2019.

UNITED NATIONS ENVIRONMENTAL PROGRAMME. Environmental Rule of Law: First Global Report. Nairobi: UNEP, 2019. Disponível em https://wedocs.unep.org/bitstream/ handle/20.500.11822/27279/Environmental_rule_of_law.pdf?sequence=1 \&isAllowed=y Acesso em: 25 set. 2019

Recebido em: 15 de setembro de 2019 .

Aprovado em: 28 de outubro de 2019. 